\title{
An analysis of workplace representatives, union power and democracy in Australia
}

David Peetz, Centre for Work, Organisation and Wellbeing, Griffith University

Barbara Pocock, Centre for Work + Life, University of South Australia

To be published as: Peetz, D \& Pocock, B, 'An Analysis of Workplace Representatives, Union Power and Democracy in Australia', British Journal of Industrial Relations, 47(4), December 2009.

Please direct correspondence to David Peetz, Centre for Work, Organisation and Wellbeing, GBS Nathan, Griffith University, Brisbane QLD 4111, Australia, email d.peetz@griffith.edu.au 


\title{
An analysis of workplace representatives, union power and democracy in Australia
}

\begin{abstract}
The purpose of this paper is to illuminate the views and experiences of workplace representatives in Australia in the context of falling union density, and to analyse factors that are most strongly associated with subjective union power at the workplace level, as perceived by delegates. The analysis relies on a large random survey of workplace delegates in eight significant Australian unions. The paper describes the situation broadly facing delegates as shown by the survey and analyses a set of factors associated with the power of workers as perceived by delegates. We find that higher levels of reported activism amongst delegates are strongly associated with greater subjective union power. We also find that self-reported delegate confidence is also strongly associated with perceptions of higher union power, as is delegate's clarity about their roles. The data also show a strong association between perceptions of democracy within the union, and union power. Support for delegates from the union office and organisers is also associated with higher levels of union power at the local level. The analysis provides some support for union renewal strategies associated with the ‘organising model' as applied in Australia and some other Anglo Saxon countries that aim to increase the activism of workplace delegates through education, the provision of support for workplace delegates and more democratic union structures.
\end{abstract}




\section{Introduction}

The last part of the twentieth century saw falls in union density throughout industrialized countries including the United States, the United Kingdom, New Zealand and Australia (Fairbrother and Yates 2003). Falls in union power and resources accompanied these falls in density. A number of Australian unions responded to this crisis by adopting organising strategies that amount to a greater focus upon new membership growth and workplace activism and a lesser focus on the servicing of existing members. This 'organising approach' was strongly fostered by the labour movement's single peak council, the Australian Council of Trade Unions (ACTU). With many variations, this 'shift to organising' has also had salience in some unions in the US, Canada, New Zealand and the UK (Fairbrother 2005; Heery et al. 2000).

The conceptualisation and analysis of an organising approach has not been without controversy in the international literature (de Turberville 2004; Carter 2006; de Turberville 2007 ). Its characteristics have differed in practice between countries, and between and even within unions in particular countries (Carter \& Cooper 2002; Peetz, Pocock \& Houghton 2007). However, an ‘organising approach' is more than a ‘useful rhetorical device’ (de Turberville 2004: 776). It suggests a union strategy that is focussed on workplace activism and membership growth, as contrasted to a form of unionism that provides services to existing, dependent member-clients (Labor Research Review 1991; Bronfenbrenner et al. 1998). The organising approach is generally taken to mean union strategy that embodies a pivotal role for workplace union delegates (representatives) in activating members, recruiting and thus reviving union membership (Bronfenbrenner, Friedman et al. 1998; Carter \& Cooper 2002; Ellem 2002; Erickson et al. 2002; Findlay \& McKinlay 2003). The organising literature - whether analytical (de Turberville 2004) or prescriptive (Crosby 2002; Crosby 
2005) - emphasises the essential role that workplace activists play in recruiting new members, creating a strong positive profile for unions in the workplace and leading local activism. Amongst other things, delegates in this model release organisers and other full-time union officers to increase organising and recruitment efforts in non-unionised sites. Thus workplace union delegates are central to union renewal (Oxenbridge 1997; Crosby 2005).

This paper examines the situation of workplace delegates in Australia. We analyse the relationship between the perceptions and experience of workplace delegates and perceptions of union power - 'subjective power' - in the workplace. Our analysis has two purposes. Firstly, we aim to illuminate, after a decade of active discussion about union renewal and steps towards an organising approach in Australia, the current state of workplace delegate structures and perceptions. Secondly, and more importantly, we aim to investigate the relationship between the characteristics of workplace delegates and perceived power, and whether the features of an organising strategy as they exist at the workplace level - including more training, support and activism by local workplace representatives - are associated with greater subjective union power.

This investigation is relevant to the discussion about union strategy (Heery and Kelly 1994). In analysing what paid officers in UK unions do, based on data collected in two waves (1980s and 2002), Heery (2006) contrasts ‘agency' and ‘articulation' union strategies. In the former, union officers activities and action are driven by their different characteristics, values and preferences: 'officers make choices in performing their role and .. these are shaped by their own values' (2006, p 464). In this account, union renewal requires changing the population of union representatives given the importance of their personal characteristics to their engagement with renewal (Heery, 2006, p 465). This is contrasted with an 'articulation' account where union renewal occurs as union officials enact (or 'articulate') centrally 
determined union policy in their work, encouraged by management and development strategies that aim to stimulate changed behaviour.

Heery's analysis of paid officials in UK unions in 2002 finds some support for both agency and articulation as factors facilitating union renewal; he concludes that 'union management matters' and that unions can shape the behaviour of officers 'through internal management procedures' especially through training and support, and that renewal of the union workforce through the recruitment of younger officers is also important.

Does this conclusion - that union management matters and that both the characteristics of union officials and the strength of their linkages with other levels of the union and the training and support it offers - affect the success of union renewal strategies in other settings? We hope that our study contributes to this discussion, analysing another level of union position in another Anglo Saxon setting - workplace delegates in Australia - where a turn to organising has been underway since the mid-1990s.

We also aim to contribute to the discussion of linkages between union power and democracy. Union power relies on identification of collective interests (Tilly 1978; Kelly 1998) and their expression amongst enough members of the group to generate a sense of common grievance (Gall et al. 2001). It also relies on collectivist attitudes: that is, awareness amongst members of the group that they have something significant in common and that they have the capacity and intent to act cooperatively, and a belief that collective effort will have effect (Frege 1997). This suggests that a renewal process which builds power in unions requires that they are able to build a sense of common purpose and a sense of efficacy (Bandura 1997). Collective power is mobilised in the interests of workers if the mechanism for collective power - the union - is responsive to the wishes and interests of the members: that is, it is democratic in practice. Employees cannot have true power in the workplace if they do not also have power and effective voice in the union. This suggests that an important 
part of union renewal is democratisation. In Fairbrother's definition (1986, p 172), union democracy is 'a condition for unions to realise their members' interests' and exists when 'members are actively involved in the formulation of union policy, in the processes of bargaining...in the election and control of delegates and officials, and in the organisation and activity of the union'. It is certainly possible for union renewal (if it is defined, for example, as growth in union density) to occur without union democracy: a centralised decision to reallocate union resources to recruitment is possible, with dividends for union membership growth and none for stronger membership or activist voice in the union. There is an argument, however, that union democracy is positively associated with union power: as Levesque and Murray put it, discussing union renewal in Canada and Mexico:

The presence of a network of shop-floor representatives reinforces the legitimacy of a proactive union agenda towards change. In other words, the dialogue between members and shop-floor representatives about union objectives in the change process greatly enhances the legitimacy of union positions. Simply put, democracy becomes a vital source of union power. (2003, p 9)

It is this connection between union democracy and union power in the context of union renewal that we also aim to investigate in this paper.

Australian unions are far from singular in character: they are distinguished by their orientation to the Labor Party (some affiliate, some do not), by their orientation to its left or right factions, by their more or less democratic character, by their level of centralisation or looser federation, and by their size, industry and occupational character and gender politics. However, they face a similar hostile context and profile of decline. Our analysis focuses upon the nature of workplace delegate experience across a number of unions - which differ from each other in a range of ways - in an effort to better understand this level of representation 
across unions and to study the relationships between delegate characteristics, democracy and union power.

The structure of the paper is as follows. We begin by considering the contemporary and historical context of unionism and the union renewal debate and workplace delegate situation in Australia. We explain our data and survey methodology and set out our approach to measuring union power and a range of relevant workplace representatives’ perceptions. We then turn to results and consider the factors associated with different levels of union power at the local level before outlining our conclusions.

\section{The context of unionism in Australia}

Through most of the last century Australian unionism operated within a 'uniquely “Antipodean” pattern of labour market regulations’ (Barry \& Wailes 2004, p430) whereby the arbitral system offered unions and union density some protection. The uniqueness of Australian unionism extended to its active parliamentary-political engagement through the Australian Labor Party, a direct descendent of Australian unions in the 1890s. The Labor governments of 1983-1996 saw close national ‘Accords’ between unions and Labor in government, and included a fundamental shift in wage determination from centralised wage fixing to decentralised 'enterprise bargaining'. Since the early 1990s, however, unions have experienced outright hostility and successive pieces of legislation have worked against union membership and union bargaining and fostered individualisation of the employment relationship. This tide culminated in the Howard Government's 'WorkChoices' legislation in 2006 which was ‘inherently anti-union’ (Isaac 2007, p 427).

Australia, not surprisingly then, is amongst those Anglo Saxon countries experiencing very sharp declines in union density (Peetz 1998). The rate of decline has been much steeper in Australia than in the UK or most other OECD countries, particularly during the 1990s. 
Figure 1 shows the trend movements in union membership and density from 1982 to 2007. Union density fell below 20 per cent by 2007, less than half the rate of twenty five years earlier. Trend density has fallen in every year during this quarter century, though the fall was most severe in the 1990s when membership was also falling precipitously. From 2000, the rate of decline in density eased as membership stabilised, but membership fell again with the introduction of the 'WorkChoices' legislation. At a cross-national level, union density does not necessarily equate to union power, as institutional arrangements, such as bargaining coverage, may confer power where density is low (for example, Germany or France (Frege and Kelly 2003)). However, declining density commonly signifies declining power, and this has certainly been the case in Australia.

The explanations for this decline are multiple: they relate to the loss of institutional protections; changes in the role of the public sector and in forms of employment contracts; increasing employer hostility to unions and anti-union policies and action by governments, especially during recent periods of conservative commonwealth and state governments; and the weakness of workplace level union organisation to deal with such challenges (1996-2007) (Peetz 1998). The persistence of decline reflects the complex set of factors behind it, which have much in common with individualisation and structural changes observed elsewhere (Frege and Kelly 2003). However, the steepness of the Australian decline reflects some particularities of Australian unionism, most notably the loss of institutional protections through a weakened centralised arbitration and award system, along with the loss of 'closed shop’ arrangements in many locations. Occupational- or industry-wide national and state standards for wages and conditions which gave unions significant power as industrial actors in an arbitral system, declined in significance from the late 1980s. Some Australian unions were highly oriented to conciliation and arbitration and employer-assisted closed shop unionism - lending support to a ‘dependency thesis’ (Howard 1977) of Australian unionism - 
while others where more oriented to activist rank and file unionism and less dependent upon arbitration. Yet the protection offered by the system quickly unravelled in the context of a changing labour market and more assertive employers and governments, and all to varying degrees were affected.

More recently, following its electoral success in late 2007, the Rudd Labor government is governing at a distance from unions, intent upon public separation in policy terms. This is ironic given that Rudd's victory was due in significant part to a very successful union-led 'Your Rights at Work' campaign against 'WorkChoices’ (Muir 2008). Nonetheless, there is no prospect of a return to compulsory conciliation and arbitration and some key elements of the Howard legacy will remain in place, making unionisation difficult in many contexts and emphasising the need for union strategies that increase union power and membership in ways that respond to the current environment.

This history and context means that Australian unions now set their course in a legislative and employment environment that is difficult for recruitment, not least because the institutional memory of unionism and its rationale is weak amongst new generations of workers and in the growing service sector, and many employers remain hostile to its reach.

\section{The organising approach in Australia}

It is no surprise that severe union density declines led the Australian union movement to consider renewal strategies from the late 1990s. While the roots of 'the organising model' lie in the US (Bronfenbrenner et al. 1998), the conceptual delineation between a 'servicing' and 'organising' strategy (which manifest themselves differently in the US and Australia) struck a chord in Australia from the 1990s where many unions - though not all - had weak workplace structures, devoted meagre resources to organising new members or worksites, relied upon tribunal-oriented union strategies and focussed resources on servicing existing members. In 
the US, the Labor Research Review (1991) drew attention to the disempowering, instrumental, legalistic and stagnating consequences of a servicing approach which offered a protective union 'service' exchange for union dues. By contrast, the organising approach offered more dynamic membership and activist involvement, recruitment of members outside traditional 'patches', and a unionism that may be more resilient, democratic and campaigning in the face of opposition (Carter \& Cooper 2002).

Historically, workplace delegate structures have had an uneven history and presence in Australia (Rimmer 1989; Benson 1991). By the 1990s, that presence was in decline. The Australian Workplace Industrial Relations Survey (AWIRS) found that workplaces with an ‘active’ union presence fell from 26 per cent in 1992, to 19 per cent in 1995 (Morehead et al. 1997, p 327). In 1993, an ACTU delegation to the US drew lessons from the US approach and recommended a shift to a stronger organising culture in Australian unions (Australian Council of Trade Unions 1993). ‘Organising Works’ was established in 1994 to train a new generation of young organisers, and by 2000 it had produced over 300 trainees (Carter and Cooper, 2002, p 726), some of whom went on to make long term contributions in unions while others met resistance and 'churned and burned' out of unions (Pocock \& Wishart 1998, p 25). The organising debate in Australia was given further impetus in 1999 with a union report, Unions@Work whose first recommendation was to ‘establish delegates, activists and collective structures at every union workplace’ (Australian Council of Trade Unions 1998, p 1). A few years later, at the release of a follow-up Future Strategies report, ACTU secretary Greg Combet recognised that 'shifting resources from servicing to organising has had variable success' and that renewed efforts were necessary and required more 'membership and collective strength in existing union workplaces', increased external recruitment and more strategic relations with the Labor Party (Combet 2003). In short, the 'shift to organising' in Australia placed considerable importance upon workplace delegates and activism, linking 
their strength to union power and the liberation of union resources for recruitment in nonunion sites.

Of course union organising is an activity undertaken by unions at local levels, and the adoption of new organising strategies was and remains uneven between unions (and within them). Many unions and branches within unions continued their habituated approaches to ‘doing unionism’ some of which involved servicing of existing members and little external recruitment of new members, while others developed extensive delegate training and activism, new recruitment methods and democratic processes. An organising approach was widely discussed and in some cases embraced, especially where Michael Crosby - Director of the Union Organising Centre at the peak council and a significant leader advancing the organising agenda - took his ‘scary graph’ of projected doom for membership and finances to a number of unions through the processes of union reviews (Heery, Kelly and Waddington make mention of similar 'scary graphs' in their account of union renewal in the UK (Heery, Kelly \& Waddington 2003,p 82)). While Australian unions have a history of left-right factionalism, including through the involvement of many of them in the Labor Party, whether and how enthusiastically an organising approach is adopted has generally been unrelated to whether a union or branch is from the 'left' or 'right' (Crosby 2000). It has had much more to do with leadership vision, the slope on the scary graphs and a sense of current or impending crisis.

A key element of the organising approach as discussed in Australia is workplace renewal: that is, workplace representative structures and networks of support that develop self-reliance and confidence among members (Australian Council of Trade Unions 1998; Crosby 2005). However, without organisational and structural renewal, workplace renewal is almost impossible, precluded by the inertia of historical structures and resource allocation. This is evident in a number of studies of renewal (e.g. Carter \& Cooper 2002). For example, 
workplace representative structures are unable to develop effectively in most workplaces if the union office does not provide training to underpin delegate development or does not practically reallocate servicing demands faced by organisers (Peetz, Pocock et al. 2007). The challenges are daunting. A large, national, random survey of Australian workers in 2007 found that 64 per cent of employees worked in workplaces where no union delegate was present (23 per cent in unionised workplaces). Almost half (48 per cent) of employees worked in workplaces without any known union members and 10 per cent did not know if any union members were present (van Wanrooy et al. 2007, p 89-91). Clearly, strengthening workplace delegate structures and presence, and through them union power, is a significant challenge in Australia but one that lies at the heart of the movement's strategy of a 'shift to organising'.

\section{Data}

Our data were collected through a survey of 2506 Australian current and former workplace delegates in late 2003 and 2004. Of those, 2350 were current workplace delegates and the remaining 156 were former delegates. The data reported here come from the 2350 current delegates (hence $\mathrm{N}=2350$, excluding those who answered 'don't know', in the tables). Delegates were surveyed in eight of Australia’s 47 unions, including five of Australia's larger unions. The eight unions are listed in Table 1. They represent workers from a wide range of industries and occupations in both the public and private sectors, include large and small unions and some that are amongst the leaders in terms of implementing organising strategies in Australia (like the Liquor Hospitality and Miscellaneous Workers Union (LHMU), Australian Services Union (ASU) and the Community and Public Sector Union (CPSU) or parts thereof), along with a majority that are probably close to the average. Most have a significant proportion of female members, with the exceptions of the Australian Manufacturing Workers Union (AMWU) and Rail, Tram and Bus Union (RTBU). Table 1 also shows the industry sectors (as defined by the Australian Bureau of Statistics) in which 
members of these eight unions are concentrated, the total employment size of these industry sectors and the rate of union density in these industry sectors in 2006, though these industry density rates do not necessarily coincide with the densities enjoyed by those unions because of overlapping industry coverage by unions. The table gives an idea of the size of the industries in which they have a presence: overall, 44 per cent of all Australian employees are included in industry sectors where these eight unions have some coverage. Thus the survey represents unions with actual and potential membership in a sizeable portion of the Australian workforce. Union density overall in the industry sectors listed in table 1 was 22.6 per cent in 2006, compared to 20.3 per cent in the total workforce. The overall density of workplace delegates in these unions is probably slightly above the average amongst Australian unions, given their attention to the development of workplace structures historically.

\section{[INSERT TABLE 1 ABOUT HERE}

The survey is one of the few large surveys of its kind in the Australian context. Approximately 325 current delegates were surveyed in each of seven of the eight unions, with a smaller number coming from the RTBU because of its smaller membership base. Delegates were selected using systematic random sampling from lists provided by unions (mostly state branches). Interviews were conducted by telephone by the call centre run by the Australian Council of Trade Unions (ACTU). Interviewers were briefed by the researchers before hand on the survey instrument. The refusal rate was below 10 per cent. In the analysis below we describe the main features of the results and then use regression analyses to investigate key relationships between workplace delegate characteristics and aspects of union renewal. We phrased questions about the union in terms of their (state) branch or division of the union, as this was the key operational level of the union with which delegates had interaction.

Respondents had been delegates for an average of 6.3 years, with 13 per cent having been delegates for 12 months or less. In 44 per cent of cases, the respondent was the only 
delegate at the workplace; 20 percent had a coordinating or leadership role in relation to other delegates at the workplace; and 35 per cent were in workplaces with multiple delegates but did not have a coordinating role (including 7 per cent who were in workplaces where no-one had a coordinating role).

The data were clearly collected in a period of major change for delegates. Some 42 per cent reported that the range of tasks expected of them in their role as a delegate had gone up over the preceding two years, just 3 per cent thought it had gone down; and 30 per cent thought that it was now more difficult to perform their role as a delegate than two years earlier, just 8 per cent thought it was easier, despite the benefits that experience might bring. Workload in their job had increased for 79 per cent of them. Yet 27 per cent were more satisfied with being a delegate, compared to 17 per cent who were less satisfied, suggesting something positive was happening.

\section{Method}

According to Kelly, industrial relations research lacks a 'clear and agreed definition of power' including union power (1998: 23). Existing literature does, however, point to a range of sources of that power, and by implication to factors relevant to its measurement.

Union density and membership trends are one measure of power that is widely accepted as an indicator of union power especially in Anglo Saxon settings (Frege and Kelly 2003; Heery, Kelly and Waddington 2003). It has limitations however: in a cross-sectional dataset, the level of union density in a workplace may reflect much more the legacy of long past mobilisations or recognition deals than the current balance of strength and one side's ability to realise its interests over the other's. Obtaining an accurate measurement through anything other than a full employee survey may also be difficult. Changes in union density may tell us more about the shifting sands of power, though measurement in a cross-sectional dataset is 
limited (it may be possible to find out whether density has risen or fallen, but finding out by how much is very problematic) and asymmetrical (it has little room to rise when density is already close to 100 per cent, or to fall when it is close to zero). These are useful but limited proxies for power, and we collected data on both, but we use them more as checks on our preferred indicator, rather than as the key dependent variables in their own right. Another way to think about union density is as an important determinant of power, but not necessarily the best measure of it.

At least as useful as pseudo-objective measures of union power may be more subjective measures. Delegates are at the front line of employee-management relations, and they observe on a day to day basis the interactions between employees, management and unions that reveal where power lies in the workplace. Their perceptions of power at the workplace might be more accurate syntheses of all the factors that contribute to power than a single, objective measure like density. (A crude analogy might be drawn with the way in which betting markets are moderately efficient mechanisms for synthesising all available information, including pseudo-objective measures such as opinion polls, to predict election outcomes (Leigh \& Wolfers 2006).) So we develop a subjective measure of power based upon the perceptions of delegates, based on an index of several indicators, and regress that against explanatory variables available in the dataset.

We make use of several aspects of power in constructing our index of subjective union power. One approach is to look at perceptions of whether the outcomes of bargaining decisions have produced benefits for members, an approach with links to the rather cautious approach taken to defining power in terms of the outcomes of decisions by Dahl (1961). Hence we include responses to a statement 'The last round of enterprise bargaining here produced outcomes that members were happy with'. Another approach is to take account of the knowledge that self-efficacy beliefs - that is, the extent to which individuals or groups 
believe they have the ability to change things - are good predictors of the actual ability of those individuals to exercise power to achieve their goals (Bandura 1997). Accordingly one variable we include is a direct measure of self-efficacy by individual union delegates: responses to the statement 'By being a union delegate, I can really make a difference to what happens to people where I work'. Applying this principle to the group, rather than to the individual, we also make use of the summative statement, 'The union has power in this workplace'. These more broad ranging approaches are consistent wit the critique of Dahl's conception of power advanced by authors such as Bachrach and Baratz (1970). Finally, as power is a dynamic process, with gains (or losses) building over time and reinforcing themselves, we are interested to see the direction of that dynamic. If workers' power is low, then in a period of change the success rate of the union at the workplace will be falling; conversely, if power is higher, the success rate will be rising. Accordingly, we include responses when delegates were asked whether they thought that 'over the past 2 years' the success rate of your union on issues at your workplace' had 'gone up, done down or stayed the same'. These four items, when combined as an index, had a Crombach's alpha of .62, indicating a respectable level of scalar reliability. Each item contributed positively to the reliability of the index.

The index has 15 possible values, ranging from 0 to 14, with a midpoint of 7 . For analytical purposes, in regression equations we use the full range of this index and treat it as a continuous variable. For descriptive purposes, however, in the cross-tabulations that follow we divide the sample into three groups: those with 'lower' subjective power (defined as values 0 to 6 , comprising about 17 per cent of the sample); those with medium power (values 7 to 9, 33 per cent of the sample); and those with 'higher' power (values 10 to 14, 51 per cent). The asymmetric nature of the index reflects the patterns of responses to the component questions. Fifty-eight per cent of delegates felt that the union had power in the workplace (20 
percent disagreed), and 62 per cent agreed that the last round of enterprise bargaining in their workplace produced outcomes that members were happy with (19 per cent disagreed). Fortysix per cent perceived an improvement in the success rate of their union on issues at their workplace, and just 11 per cent perceived a decline. Two thirds reported a sense of selfefficacy, and felt that by being a delegate, they could really make a difference to what happens to people where they work.

Separately, we measured union density by asking respondents to estimate the 'percentage of people in your part of the workplace' who are in the union. We asked for their 'part of the workplace' to maximise accuracy and most closely proxy the power of their particular union. Those who could not make an estimate (one sixth) were asked to identify a quartile range within which it was located; this was then converted into the average density for that particular quartile across the rest of the sample. We measured movement in union density by simply asking whether in the past two years 'the level of unionisation in your part of the workplace' had gone up, gone down or stayed the same. On average, delegates reported that about two-thirds of workers in their part of the workplace were union members. Thirty five per cent perceived that the level of unionisation in the workplace had increased over the preceding two years, while 19 per cent perceived a decrease. We considered the effects of including one or both into the index of power, but neither added appreciably to the reliability of the index and we wanted to be able to look at the relationships between subjective power and these pseudo-objective measures.

We use OLS regression to predict subjective power (based on the full index), using a range of variables depicting various elements of activism and union behaviour as explanatory variables. The descriptors of the variables are in Appendix A. The variables were chosen because of their relationship to concepts in the organising model. The organising model posits that unions will build up workplace strength when delegates and workers are given the 
skills and resources to undertake actions themselves in support of their own interests, rather than relying on the organiser or other union officials to solve problems on their behalf. It follows within this logic that delegates need to be trained, and that organisers should mentor delegates, following up issues raised in training (Peetz, Webb \& Jones 2002) and teaching them skills on-the-job. So we asked respondents whether they had received delegate training, what they had been trained in, and their overall assessment of the training they received. We asked them whether they believed their organiser had taught them many valuable things about being a delegate, and how often they had contact with their organiser and other paid union staff. The organising model depends on the union office, including the organiser, providing various forms of support to workplace delegates. So we asked respondents to rate the quality of support they received from the union on eight separate issues, along with the overall effectiveness of the support they received from the union and whether they felt that, within the previous two years, the level of support they received from the union had gone up or down, and who was the person who was most use to them in terms of helping them do their job as a delegate well. The organising model focuses on activism by delegates, so we asked questions about the activities that delegates undertake. We might expect that delegates' ability to undertake the more extensive functions assigned them under the organising approach would require they have clarity on what their role entails and feel confident in undertaking their tasks. Accordingly, we sought information on role clarity and confidence. The organising model does not just aim to increase activism by delegates, but also to engage ordinary members in union activities, in no small part to spread the burden from delegates, who have considerably increased responsibilities under this model. So we asked whether they found it easy to get members to share in tasks. We also asked a series of questions about the barriers that prevented delegates from being more involved in the union, including lack of support from members, family responsibilities and increasing workloads, and whether they 
though being a delegate took up too much time or that the union put too much responsibility onto delegates. As the rhetoric of the organising model talks about empowering members at the workplace to make decisions instead of having them made on their behalf by the union, we asked a series of questions that touched on various aspects of democracy within the union, including whether delegates had a lot of influence in the union, whether members had a lot of say in determining claims on the employer, whether union decisions were made without adequate consultation, and whether the amount of influence of members within the union had risen or fallen within the previous two years. The union renewal agenda also talks about making unions more inclusive, so we asked whether women's issues were paid a lot of attention by their union. We also sought information on some of the external constraints that may impede union power, including the degree of opposition or support from their employer, changes in job security, and the increased use of contingent employees.

On a couple of these concepts we developed indices. Earlier research, based on a written survey of delegates in a union in the finance sector, had developed 14-item indices of ‘current activism’ and 'long term activism' by delegates, based on a list of actions they had undertaken in the previous two months, and since they had become a delegate (Peetz, Webb et al. 2002). Being constrained for time in this telephone survey, we analysed the data from that earlier survey to identify the six items that could best be used to create an 'index of delegate actions' for this telephone survey. Thus we asked respondents whether they had, within the preceding six months: answered queries from members (93 per cent said they had); gathered input from colleagues to feed back to the Union office (76 per cent); recruited someone to the union (69 percent); participated in a delegates’ meeting (68 per cent); handled a dispute for a member or members (55 per cent); and mobilised colleagues for some form of collective action (eg signing petitions/going on strike) (54 per cent). All six items contributed positively to the reliability of the index, for which $\alpha=.64$. The regression equation discussed below 
(Table 2) uses the full range of the activism index, which has seven possible values ranging from 0 to 6 . For crosstabulations we divided delegates into three roughly similarly sized groups, and labelled them high, medium and low activism.

Similarly, we wished to assess the impact of confidence on power. Earlier research had shown the importance of confidence in shaping delegate activism, and had developed a 6-item index of delegate confidence (Peetz, Webb et al. 2002). Again, to deal with time constraints in our survey, we tested the components of that earlier index to identify the three most important indicators of confidence. This produced an index for which $\alpha=.79$ in our survey, based on 'how confident' respondents felt (along a five point scale) about the following three items: answering queries from members (28 per cent felt very confident, the highest point on the scale); participating in a meeting of delegates (41 per cent); and being involved in a workplace campaign (33 per cent).

\section{Some determinants of subjective power}

The results seeking to predict subjective power are summarised in Table 2, which depicts four equations. Equation 1 is the preferred equation overall, and omits those variables which were not significant in the final equation. The entered variables explained 43 per cent of the variance in subjective power, which is respectably high for a cross-sectional dataset. Equation 2 includes one additional variable, on whether delegates were trained. Equations 4 and 5 relate only to trained delegates, to enable a focus on the perceived effectiveness of training. Missing data are dealt with through listwise deletion, which reduces the effective sample size from 2350 to 1688 in equations 1 and 2, as a number of delegates responded 'don't know' to at least one question. We tested an alternative approach, substituting means where data were missing, which maintained the sample at 2350 but produced a weaker degree 
of explanatory power (adjusted $r^{2}=.385$ ). With one exception, the variables which were significant in the original form of the equation were also significant in this high- $\mathrm{N}$ version, and while some altered their level of significance the order of the top six variables was unchanged. We prefer the greater precision obtained through the deletion of missing observations, while acknowledging that the smaller $\mathrm{N}$ may increase the chance of a false negative.

[Insert table 2 about here]

From equations 1, 2 and 4 we see that the level of activism amongst delegates, measured by our index of delegate actions, is one of the strongest correlates of subjective power in accord with the principles of the organising approach. It is plausible, and indeed likely, that the causal relationships run in both directions: that is, high activism is causing higher power, which fosters and reinforces an environment which facilitates high activism. Experiencing successful outcomes from actions is likely to encourage workers to do such things again - and create more work for delegates in the process. However, our finding of a strong association between power and activism means that union strategy that builds workplace activism with the aim of fostering workplace power is not contradicted.

Another key ingredient in subjective power shown in Table 2 is delegate confidence. The more confident delegates felt about undertaking various activities, the greater was subjective power. Again, the size of the coefficient might reflect some feedback effects here (the more power delegates believe the union has in the workplace, the more confident they may feel), but we note that this is measuring how confident they feel about specific tasks they as individuals undertake. A positive relationship here makes sense in the context of earlier research showing higher confidence enhances delegate activism (Peetz et al. 2002). Given the potential for feedback effects with both delegate actions and confidence, and the possibility that this might affect other variables, we exclude them from equation 4 but include them in 
equation 5. Comparing the two equations reveals that the effects on other variables is minor in most cases. Removing these variables increases the significance of organiser mentoring and role clarity in explaining power, suggesting that one of the key ways in which these variables (discussed below) boost power is through their impact on delegate confidence.

The regressions also show that perceptions about role clarity were strongly associated with higher perceptions of union power. Fifty-nine per cent of those who felt they were clear about their role and what was expected of them as a delegate were in workplaces with high subjective power, compared to only 27 per cent of those who were unclear about their roles. There is not much likelihood of major feedback effects here, in what appears to be a simple and plausible causal relationship. If delegates know what is expected of them, and how to do their job, they are more likely to be able to mobilise resources for the effective use of power. We discuss other important relationships in the sections that follow.

For a union to succeed in creating a common social identity amongst its members, it needs to demonstrate that it takes seriously the concerns of all its members. One test of this is whether the union takes women's issues seriously. The regressions showed that local power was higher where the union was perceived as paying attention to women's issues, though the significance of this varied between equations. In total, 58 per cent of delegates (including 60 per cent of female delegates) agreed their branch of the union paid a lot of attention to women's issues amongst its members.

Having also collected data on levels of and movements in union density, we also undertook a reality check on our data, testing whether the variables that showed up as significant in Table 2 also correlated with these less subjective, but less precise measures of power. These comparisons are shown in table 3. As can be seen, almost all the variables that correlated with our subjective measure of power also correlated with density and movement in density, with the same signs though with typically smaller coefficients. Regression 
equations predicting density or movements in density had considerably lower predictive power than did the equations in table 2 regarding subjective power. But what if, instead of treating union density as a proxy for power, we treat it as a determinant of power? We did the later in equation 3 of table 2, including both the estimated level of density, and the movement in it, into the regression model. As we would expect, both measures show up as strongly significant. The direction of movement in unionisation was a stronger predictor of subjective power than the level of density, consistent with our concerns about the limitations of density as a true measure of power. With one exception, all other explanatory variables retained significance, often at similar levels of significance. That variable was our index of delegate actions, which became significant at only the 10 per cent level, suggesting that delegate's activities increase as density rises, and indicating again that the relationship between activity and power is two way. Interestingly, while strongly significant, the density measures were still not the most powerful predictors of subjective power - we will come to those shortly.

[table 3 about here]

Other variables collected in the survey were entered into earlier iterations of the equations but did not show up as significant. They were therefore omitted from the final form of the equation. They included such items as: whether their workload was increasing or an obstacle to their further participation in the union; whether they thought doing union work took up too much time; whether the union put too much responsibility onto delegates; and how often they were in contact with the union organiser or office. For example, 15 per cent felt that the union put too much responsibility onto delegates and 25 per cent thought doing union work took up too much time. When we asked delegates about the barriers to their greater involvement in the union, the most common single response was workload. Yet neither it nor the other factors listed above separately influenced subjective power. Some (such as increasing workload and the view that union work took up too much time) did not 
even have bivariate correlations with power. We can say that a broadening out of roles was affecting many delegates and that the effects of work intensification - which are widely observed in Australia (Allan, O’Donnell \& Peetz 1999) - were complicating the role and work of delegates. While they did not directly affect subjective power at the workplace, some of these might influence subjective power indirectly (eg frequency of contact, which has a bivariate correlation with power, appears to influence how well delegates were mentored by their organiser), or they may influence power over a longer period, in ways unobservable through these regressions (eg excessive work might lead to burnout and quitting).

\section{The relationship between subjective power and democracy}

How did delegates perceive democracy within the union? Three-fifths thought members had a lot in say in determining the content of an enterprise bargaining claim and only 22 per cent complained that there was not enough consultation with members before decisions were made. Nearly half agreed that delegates had a lot of influence in the branch. Almost a quarter perceived that the amount of influence members had in the union had gone up over the previous two years (10 per cent said it had gone down).

These figures matter because the most powerful set of influences on subjective power concerned aspects of democratisation within the union. As shown in Table 2, the three strongest explanatory variables were all related to this concept: whether members had a lot of say in determining the content of claims made in enterprise bargaining; whether delegates have a lot of influence in the union branch; and whether the influence of members in the branch has been increasing over the past two years. Clearly, the more power that delegates perceive that they have in influencing the union, the more power they perceive they have in the workplace as well. The three aspects of democratisation that dominate the regression equation appear, however, to be distinct concepts. When we tried to group them into an index of democracy, it was not quite reliable enough to generate a satisfactory $\alpha$. 
It might be objected that the construction of the subjective power index biases towards this result, because one of its four components is the statement 'The last round of enterprise bargaining here produced outcomes that members were happy with', and the strongest predictor is the variable 'In an enterprise bargaining campaign, members here have a lot of say in determining the content of the claim', which while conceptually different still refers to enterprise bargaining. However, if we take the summative question 'The union has power in this workplace', and regress it against the same explanatory variables, we find that a democracy variable ('delegates have a lot of influence in this branch') is still the strongest predictor, and the third strongest predictor (behind density) is whether members have a lot of say in bargaining claims. We note also from Table 3 that change in member influence in the union was, by far, the biggest correlate of movement in union density.

While there is a remote prospect of reverse causality (ie that more powerful unions in the workplace cause more internal union democracy), it is not immediately evident why this would occur, particularly with such strength. But it is not so hard to see why greater democracy would lead to greater power: when members feel that they 'are' the union, they are more likely to act in solidarity to successfully advance their interests. Promoting the idea that members 'own' the union is one of the core principles behind the organising model. In one of his classic works, Hyman (1975) draws the distinction between two types of power, and pointed out that a union cannot have power for its members unless it also exercises power over them, to ensure solidarity in collective action. To this we would add the suggestion that union members cannot have power over the employer unless they have power in the union.

\section{Power and networks of support}

An important source of support for delegates is the networks they develop - with union staff, other delegates and members. Several variables related to these networks were associated with power (Table 2). The regressions show that subjective union power was 
significantly lower where delegates reported that a lack of support from their fellow members was an obstacle to being more involved in the union. Subjective union power was significantly higher where delegates reported an increase in the level of support that they received from the union office. It was higher where they agreed that their organiser had taught them many valuable things about being a delegate and where they scored the union as effective in showing them how to develop networks of people to help them.

Given the importance of these networks, then, what is the nature of networks for delegates? A majority of delegates (51 per cent) agreed they had a lot of contact with other delegates at their workplace (35 per cent disagreed). However, only 23 per cent agreed (61 per cent disagreed) that they had a lot of contact with delegates from their own union in other workplaces, and only 12 per cent agreed (78 per cent disagreed) that they had a lot of contact with delegates from other unions. There were some signs that contact between delegates was increasing: 28 per cent said they were now working more closely with other delegates than two years earlier (11 per cent said less closely).

However, contact with their organiser was more important for the majority of delegates. We asked respondents which person, inside or outside the union, was most use in helping them do their delegate job well. For half of respondents this was the union organiser. The second most common response was someone else from the union office. In total, 62 per cent cited paid union officials as being the most helpful person to them. Only 25 per cent referred to other delegates or members - mostly from their own union at the same workplace.

Union offices provide a variety of support to their delegates. We asked delegates to rate, on a scale of 1 to 5 , how effective several types of support were for them. In total, 24 percent of respondents described the overall level of support the union gave them as being 'very effective', and 8 per cent gave one of the lowest two ratings. The average rating was 
3.91. Unions were rated strongly for giving support around industrial action and providing news and information, and not so strongly for keeping in contact or making training available.

There were general signs of improvement, with 37 per cent saying that the support they got from the union office had gone up in the past two years, although 8 per cent said it had gone down. Despite this, there was still a sense of crisis about the union amongst a minority of delegates: 27 per cent agreed (and 58 percent disagreed) that if their branch of the union did not do things differently, it would eventually disappear.

We compared how each of the above forms of support correlated with the overall index of subjective power. Unfortunately, the most important form of support - by a small margin was the one on which unions performed worst: support in showing delegates how to develop networks of people who could help them. Delegates rated unions poorly in showing delegates how to network with people who could help them (on a scale of 1 to 5 , the average score was below 3, the only item on which union support scored so poorly). This variable was significant in the regression equations covering all delegates, and suggests a gap in union's ability to build power at the workplace arises from their failure to adequately build networks of support for and between delegates.

Some 45 per cent of respondents nominated lack of support from members as something that stopped them from being more involved in the union. The regressions in Table 2 indicated that lack of support from members had a significant negative effect on subjective power. Only 33 per cent agreed that members in their workplace were generally active whereas 45 per cent did not. This was also reflected in the burden on delegates: only 27 per cent of delegates found it easy to get other members to help share in union tasks, while 54 per cent did not. These data suggest that activating members to become involved in union activities is still a major problem for Australian unions that they have not successfully addressed. There were positive, albeit mixed, signs about change: 30 percent said that 
activism amongst members had increased over the previous two years, while 22 per cent said it had decreased.

\section{Training}

Previous research in Australia has shown that training is an important factor in promoting organising approaches, and indeed in promoting activism (Peetz et al. 2002). Some 57 per cent of delegates who had received training were in workplaces with high subjective member power, compared to only 42 per cent of delegates who had not received any training. Despite this significant correlation, whether delegates had been through training was not, in itself, significant in explaining subjective power in regression equation (2) which covered all employees. This is because the effect of training is indirect: undertaking training affects the variables that in turn directly influence subjective power. It seems that undergoing training increases power because it increases the confidence $(r=.27)$ that delegates require in order to be activists in the workplace ( $\mathrm{r}=.23$ with our index of delegate activities), it increases the role clarity of delegates $(\mathrm{r}=.28)$, and it increases the likelihood that delegates will believe they have been shown how to develop networks of support $(r=.20)$. Several of these findings are in accord earlier other Australian analysis (see Peetz et al. 2002).

Training was clearly an area where more needs to be done. Only sixty-two per cent of delegates had received formal union training. Many who had been delegates for some years had received no training. Overall, nearly half of delegates nominated that 'I don’t feel as confident or well trained as I'd like to be' as a reason for their not being more involved in the union.

In at least one respect training had an impact that persisted even after other variables were controlled. The perceived usefulness of training was highly significant in predicting local power in regression equations 4 and 5 of Table 2 (these equations only related to 
delegates who had been trained). That is, there are other beneficial impacts that training has that are not fully captured by our explanatory variables.

\section{Organisers as mentors}

Alongside training, the nature of the relationship between delegate and organiser was also important. Earlier research shows the importance of organisers following up on training through direct contact with the delegate, as without this the benefits of training for activism are often lost (Peetz et al. 2002). Table 2 shows that a strong predictor of subjective power is whether delegates agree that 'my organiser has taught me many valuable things about being a delegate'.

The data suggest, in fact, that total mentoring provided by the organiser - usually including informal or 'on the job' training, but sometimes also including formalised training (sometimes training in Australia is provided by organisers and sometimes by specialist trainers) - might be even more important than formal training sessions. This organiser mentoring variable had a stronger correlation with the subjective power index $(r=.39)$ than whether delegates had received training $(\mathrm{r}=.16)$. In fact, as shown in Table 4, mentoring correlated more strongly than did training with a range of 'positive' attitudes amongst delegates. For example, while training helped delegates develop networks ( $\mathrm{r}=.19)$, organiser mentoring was even more influential in helping the delegate develop networks $(r=.49)$. Similarly, when we restricted the analysis to delegates who had been trained, organiser mentoring was a stronger predictor of good outcomes for delegates than was the overall perceived effectiveness of training (columns $3 \& 4$ of Table 4 ). This suggests that the most successful delegates were those where the organiser was teaching them useful things - like how to build networks. And knowledge is power in the union: those delegates who had been well mentored by their organiser were more likely to say that delegates had influence in the union. This set of results provides further evidence in support of a shift to an organising 
approach that focuses on building the capabilities of local delegates through training and mentoring. However, it also highlights some problems.

We asked delegates who was the most use to them in helping them do their job as a delegate well: by far the most common response was the organiser. Unfortunately many were not seeing them very often. While 26 per cent said they had personal contact with their organiser three or more times a month, for 39 per cent it was less than once a month. Contact with anyone else from the union office was even rarer, with only 13 per cent having such contact three or more times a month, and 68 per cent having such contact less than once a month. There were clearly mixed views on organisers: 44 per cent agreed that their organiser had taught them many valuable things about being a delegate, but a disturbingly large minority (32 per cent) disagreed with this proposition. It seems that union weaknesses in this area may be impeding union power in the workplace.

\section{Managerial opposition}

While managerial opposition to unions is important in explaining union outcomes, there has been relatively little research about what level of management is most hostile or matters most. We asked respondents how they would categorise their supervisor's attitude, and their company's or organisation's attitude towards them. They received more support from their immediate supervisors: 54 per cent of whom were considered supportive and just 14 per cent hostile. By contrast only 38 per cent of their organisations were considered supportive and 23 per cent hostile. Twenty-one per cent reported that management opposition to their role as a delegate had gone up over the past two years, whereas it had declined for just 10 per cent. This increased opposition appeared to be coming from both levels, though the correlation was stronger with supervisor's opposition $(\mathrm{r}=.32)$ than with organisational opposition $(\mathrm{r}=.25)$.

Overall, however, outcome variables seem to be more related to the attitude of the organisation than that of the supervisor. 
The regression analysis (Table 2) showed that the overall company stance was more important that that of the delegate's boss in explaining union power: oth were significant, but the company's position more so. The higher management opposition, the lower was subjective power. As we would expect, subjective power was also significantly lower where job security had fallen. This occurred in 35 per cent of workplaces (and rose in just 18 per cent).

While managerial opposition to unions is important, this needs to be put in context. Overall, in our model, union-related variables explained more of the variance in subjective union power than did management-related variables. We separately predicted subjective power using the six best management-related variables, ${ }^{1}$ and then predicted it using the six best union-related variables. ${ }^{2}$ The former equation explained 5 per cent of the variance in subjective power; the latter equation explained 37 percent of it. Subject to the limitations of the data (we collected less information about management than about unions), this implies that, in workplaces with union delegates, what unions do matters more for subjective union power than what employers do. This is consistent with other historical data, which showed that when unionism declined markedly during the 1990s, it was in workplaces where unions lacked effective and active delegates that deunionisation or union collapse was most likely to take place in response to management union avoidance strategies. In workplaces with an active, rather than passive, union presence, deunionisation was unlikely to occur despite potentially hostile management strategies (Peetz 1998). Of course, the data from our survey tell us nothing about what happens in workplaces without delegates. It stands to reason that the relative influence of management actions would be much greater there.

\footnotetext{
${ }^{1}$ Whether the respondent's boss was an obstacle to further involvement in the union; company's attitude to union activities; supervisor's attitude to union activities; change in management opposition; change in job security; change in casual or temporary employment.

${ }^{2}$ Organiser mentoring; a lot of attention is paid to women's issues; delegates have a lot of influence in the union; members have a lot of say in bargaining claims; clear expectations of delegate; change in support from union office.
} 


\section{Conclusions}

After decades of decline, Australian unions continue to face difficult times. However, our analysis of delegates in eight Australian unions suggests that the role of delegates, at least in their perception, is changing in many places, and that the orientation to more workplace activism - where it exists, which is far from everywhere - is associated with greater union power.

At the time of our survey, delegates liked their role and they felt that it made a difference. However, their job was becoming harder as more things were being asked of them and general work demands increased. A majority of delegates were trained, but more needed to be trained, if they were to be able to manage (and enjoy) the wider range of tasks that unions expect of them. Our study shows that higher levels of training are associated with higher levels of subjective union power. Support for delegates provided by the union office was fairly good, but its absence remained a barrier to further involvement in the union for one in six delegates. Union support for delegates was weak in some areas, particularly in developing networking skills - and it is these skills which seemed to be most strongly associated with greater union power.

Many delegates were reliant on their organiser, and some organisers (it would appear, a minority) were not seen as effective enough in teaching delegates important skills and probably do not keep in contact with them often enough. This highlights the importance, not only of training delegates, but also of effective training of organisers, as in many areas (such as networking skills) the mentoring they provide appears more important than what is learned in formal training. 
Management opposition was a problem for a minority of delegates, but it was a growing problem. Most delegates felt personally involved in the union, but many had great trouble getting their fellow members involved and persuading them to share the tasks of union activities. Activism was perceived as increasing, but from a low base. Member and delegate involvement in the union - expressions of union democracy - were improving, but still have a long way to go. So too with union power, and union wins at the workplace.

We found a strong association between subjective member power and a number of factors associated with the organising agenda. While the causal linkages between these factors are not always established, our findings are consistent with the central tenets of the organising model: that building workplace activism through building confidence, training, support and delegation of authority to the workplace level will result in greater union power. This provides some affirmation for the organising strategies being pursued to varying degrees by the Australian movement and in other Anglo-Saxon countries, at least in relation to workplaces with union delegates.

There is also support for the linkages between union power and democracy. Local union power was perceived as stronger when unions were more democratic, with power located more in the hands of members and delegates. In our definition, democratic organisation related to a perception that members had influence in the decisions of the union, including those that directly affected them (such as the content of claims against the employer). Many delegates felt that their influence within the union was increasing. Our study indicates that power in the workplace is associated with effective democratic voice within the union.

Subjective power was also stronger where delegates were confident, active, had clear roles and had strong networks of support at the workplace and in the union office, particularly through the organiser. Subjective power was stronger where the employer (and the delegates' supervisor) were supportive of the union delegate's role, and where job security was not 
declining. However, our model indicates that, in workplaces with union delegates, employerrelated factors were less important in explaining union power than union-related factors. This is not to doubt the effectiveness of employer opposition to unions in Australia in recent years, but rather to emphasise that, in the end, unions need to look to their own actions to understand where and why they have lost power, and what can be done about it.

We concurr with Heery (2006) that union strategy matters. We find that there is good reason for having confidence in the 'turn to organising' that is underway in Australia given the positive relationships we find between union power and an organising approach. In our analysis, workplace renewal affects perceived local union power by enhancing the confidence, activism, and local networks of support for delegates. Aside from its association with workplace power, the organising approach is also aligned with democratisation which emerges as a crucial factor in building power. The development of support networks from the union office for workplace delegates, and role clarity for delegates are also important. These findings confirm what studies of other levels of union strategy suggest: that union delegates have agency, and that agency can be reshaped and strengthened through training and support. This suggests that the articulation of union strategy across different levels of the union is also important in shaping union power. In other words 'union management matters' and both agency and articulation are important elements in managing change (Heery et al. 2006: 465). There are positive signs of change - in workplace delegates’ perceptions at least - about the situation of unions in some workplaces. Whether these signs will be enough to stem the decline in union density and power in Australia remains an open question. Our analysis suggests that some unions now are modestly equipped at the workplace level in many locations. However, in other places delegates lack the confidence, skills, training, mentoring, support networks and effective voice within their unions that is associated with greater efficacy and power. There is much work ahead for Australian unions to do. 


\section{REFERENCES}

Allan, C., M. O’Donnell \& D. Peetz (1999). "More Tasks, Less Secure, Working Harder: Three Dimensions of Labour Utilisation." Journal of Industrial Relations 41(4): 519535. December

Australian Council of Trade Unions (1993). United States mission report: Priority One, the organinising trail'. Melbourne, ACTU.

Australian Council of Trade Unions (1998). Unions@Work. Melbourne, ACTU.

Bachrach, P. \& M. S. Baratz (1970). Power and Poverty: Theory and practice. New York, Oxford University Press.

Bandura, A. (1997). Self-efficacy : The exercise of control. New York, W.H. Freeman \& Company.

Barry, M. \& N. Wailes (2004). "Contrasting systems? 100 years of arbitration in Australian and New Zealand." Journal of Industrial Relations 46(4): 430-447.

Benson, J. (1991). Unions at the Workplace. Melbourne, Oxford University Press.

Bronfenbrenner, K., S. Friedman, R. W. Hurd \& R. A. Oswald, Eds. (1998). Organising to Win. Ithaca NY, ILR Press.

Carter, B. (2006). "Trade union organizing and renewal; A response to de Turberville." Work, Employment and Society 20(2): 415-426.

Carter, B. \& R. Cooper (2002). "The organizing model and the management of change: A comparative study of unions in Australia and Britain." Relations Industrielles 57(4): 712-742. Fall.

Combet, G. (2003). Speech on the launch of Future strategies. Organising Conference, Sydney, ACTU. 8 May 2003.

Crosby, M. (2000). Union Renewal in Australia. Trade Unions 2000: Retrospect and Prospect. G. Griffin, National Key Centre in Industrial Relations, Monash University.

Crosby, M. (2002). Down with the dictator: The role of unions in the future. Working futures: the changing nature of work and employment in Australia. R. Calllus and R. Lansbury. Sydney, Federation Press: 115-131.

Crosby, M. (2005). Power at work: Rebuilding the Australian union movement. Sydney, Federation Press.

Dahl, R. A. (1961). Who Governs? Democracy and power in an American city. New Haven, Yale University Press. 
de Turberville, S. (2004). "Does the 'organizing model' represent a credible union renewal strategy?" Work, Employment and Society 18(4): 775-794.

de Turberville, S. (2007). "Union decline and renewal in Australia and Britain: Lessons from closed shops." Economic and industrial democracy 28(3): 374-400.

Ellem, B. (2002). The power of place and scale: union renewal in the Pilbara. Celebrating Excellence, Queenstown, Association of Industrial Relations Academics of Australia and New Zealand. February.

Erickson, C. L., C. L. Fisk, R. Milkman, D. J. B. Mitchell \& K. Wong (2002). "Justice for janitors in Los Angeles: Lessons from three rounds of negotiations." British Journal of Industrial Relations 40(3): 543-67. Sep 2002.

Fairbrother, P. (1986). "Union Democracy in Australia: Accommodation and resistance." Journal of Industrial Relations 28(2): 171-190. June.

Fairbrother, P. (2005). "Redicovering union democracy: Processes of union revitalisation and renewal." Labor HIstory 46(3): 368-376.

Fairbrother, P. \& C. A. B. Yates (2003). Unions in Crisis, Unions in Renewal? Trade Unions in Renewal: A comparative study. P. Fairbrother and C. A. B. Yates. London, Continuum: 288 p.

Findlay, P. \& A. McKinlay (2003). "Union organising in 'big blue's' backyard." Industrial Relations Journal 34(1): 52-66. March.

Frege, C and J. Kelly (2003) 'Union strategies in comparative context' Varieties of unionism: Strategies for union revitalization in a globalizing economy. Frege, D and J. Kelly (eds) Oxford University Press, Oxford pp 31-44.

Frege, C. M. (1997). "Does economic transformation undermine union collectivism? The case of East German textile workers." Industrial Relations Journal 28(3): 163. Sep 1997.

Gall, G., P. Bail, K. Gilbert, G. Mulvey \& P. Taylor (2001). Worker mobilisation, collectivism and trade unionism in call centres in Britain, Cardiff University, Cardiff Business School. 10-11 September.

Heery, E. (2006). "Union workers, union work: A profile of paid union officers in the United Kingdom." British Journal of Industrial Relations 44(3): 445-471.

Heery, E., J. Kelly \& J. Waddington (2003). "Union revitalization in Britain." Eurpean Journal of Industrial Relations 9(1): 79-97.

Heery, E., M. Simms, R. Delbridge, J. Salmon \& D, Simpson (2000) 'The TUC's Organising Academy: an assessment’ Industrial Relations Journal Vol 31 No 5, pp 400-415 
Heery, E. and J. Kelly (1994) Working for the Union: British Trade Union Officers, Cambridge University Press, Cambridge.

Howard, W. A. (1977). "Australian Trade Unions in the Context of Union Theory." Journal of Industrial Relations 19(3): 255-173. September.

Hyman, R. (1975). Industrial Relations: A Marxist Introduction. London, MacMillan.

Isaac, J. E. (2007). "Reforming Australian industrial relations?' the 21st Foenander Lecture, 28 August 2006." Journal of Industrial Relations 49(3): 410-435. June

Kelly, J. E. (1998). Rethinking Industrial Relations: Mobilization, collectivism, and long waves. London ; New York, Routledge.

Labor Research Review (1991). "An organising model of unionism." 17.

Leigh, A. \& J. Wolfers (2006). "Competing Approaches to Forecasting Elections: Economic Models, Opinion Polling and Prediction Markets*." Economic Record 82(258): 325340. September.

Levesque, C. \& G. Murray (2003). Union bargaining power in the global economy: A comparative study of workplace change and local unions in Canada and Mexico. Thirteenth IIRA World Congress, Berlin. 12 September.

Morehead, A., M. Steele, M. J. Alexander, K. Stephen \& L. Duffin (1997). Changes at Work: The 1995 Australian Workplace Industrial Relations Survey. South Melbourne, Longman.

Muir, K. (2008). Worth Fighting For: Inside the Your Rights at Work Campaign. Sydney, University of NSW Press.

Oxenbridge, S. (1997). "Organizing Strategies and Organizing Reform in New Zealand Service Sector Unions." Labor Studies Journal 22(3): 3-27.

Peetz, D. (1998). Unions in a Contrary World: The future of the Australian trade union movement. Cambridge, Cambridge University Press.

Peetz, D. (2005). "Trend analysis of union membership." Australian Journal of Labour Economics 8(1): 1-24.

Peetz, D., B. Pocock \& C. Houghton (2007). "Organisers' Roles Transformed? Australian Union Organisers and the Shift to an Organising Approach." Journal of Industrial Relations 49(2).

Peetz, D., C. Webb \& M. Jones (2002). "Activism amongst workplace union delegates." International Journal of Employment Studies 10(2): 83-108. October. 
Pocock, B. \& J. Wishart (1998). Organising Our Future: What Australian Unionists Can Learn from US Labour's Fight Back. Centre for Labour Research Research Paper Series No 9. Adelaide, University of Adelaide.

Rimmer, M. (1989). Work Place Unionism. Australian Unions: An Industrial Relations Perspective. W. Ford and D. Plowman. Melbourne, Macmillan: 122-144. Tilly, C. (1978). From Mobilization to Revolution. New York, Random House. van Wanrooy, B., S. Oxenbridge, J. Buchanan \& M. Jakubauskas (2007). Australia at Work: The Benchmark Report. Sydney, Workplace Research Centre, University of Sydney. September. 
Figure 1 Union membership ('000s) and density, trend estimates, 1982-2007, Australia

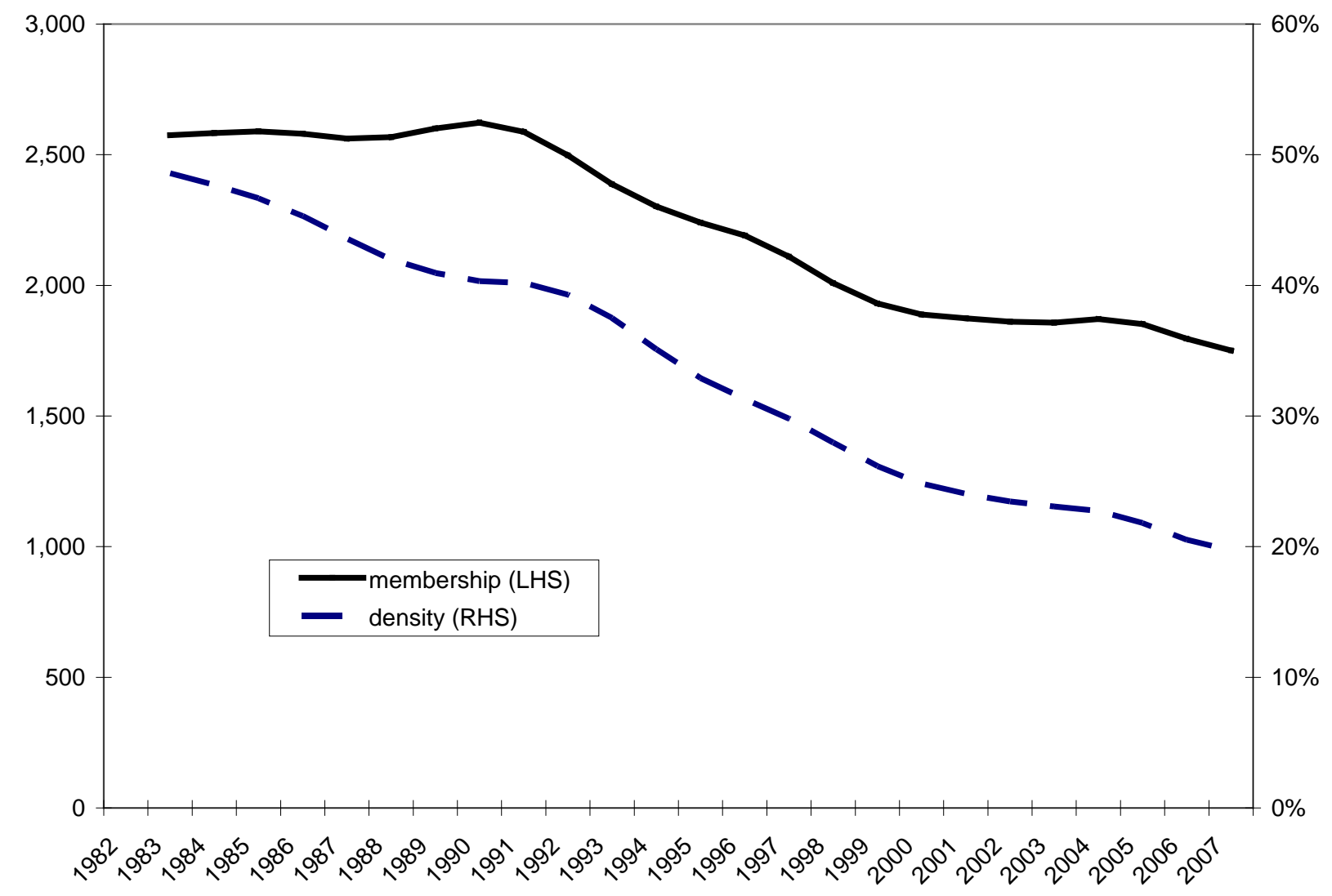

Source: Calculated from ABS Cat No 6310.0 using methodology in Peetz 2005. 
Table 1 Unions included in delegates survey

\begin{tabular}{|c|c|c|c|c|}
\hline Union & Who it represents & $\begin{array}{l}\text { Approximate industry sectors } \\
\text { where it is concentrated (1) }\end{array}$ & $\begin{array}{c}\text { Employees } \\
\text { in sector } \\
\left({ }^{\prime} 000\right) \\
(2006)(2)\end{array}$ & $\begin{array}{c}\text { Union } \\
\text { density } \\
\text { in sector } \\
(2006)\end{array}$ \\
\hline $\begin{array}{l}\text { Australian Education } \\
\text { Union (AEU) }\end{array}$ & $\begin{array}{l}\text { teachers, teaching assistants, } \\
\text { educators (public sector) }\end{array}$ & Preschool and school & 483.4 & 43.8 \\
\hline $\begin{array}{l}\text { Independent Education } \\
\text { Union (IEU) }\end{array}$ & $\begin{array}{l}\text { Teachers, teaching assistants, } \\
\text { educators (private sector) }\end{array}$ & Preschool and school & 483.4 & 43.8 \\
\hline $\begin{array}{l}\text { Australian } \\
\text { Manufacturing Workers } \\
\text { Union (AMWU) }\end{array}$ & $\begin{array}{l}\text { production workers, apprentices, } \\
\text { skilled trades and technical } \\
\text { workers }\end{array}$ & Manufacturing & 932.5 & 23.1 \\
\hline $\begin{array}{l}\text { Australian Services } \\
\text { Union (ASU) }\end{array}$ & $\begin{array}{l}\text { local government, childcare, } \\
\text { private sector administrative and } \\
\text { clerical workers, community } \\
\text { services and call centre workers } \\
\text { and clerical and administrative } \\
\text { workers in utilities like energy, } \\
\text { water and the airlines }\end{array}$ & $\begin{array}{l}\text { Admin, support and other } \\
\text { Services, social assistance }\end{array}$ & 839.4 & 10.7 \\
\hline $\begin{array}{l}\text { Community and Public } \\
\text { Sector Union (CPSU) }\end{array}$ & $\begin{array}{l}\text { Clerical and service workers and } \\
\text { middle managers }\end{array}$ & Public administration & 424.7 & 35.4 \\
\hline $\begin{array}{l}\text { Liquor Hospitality and } \\
\text { Miscellaneous Workers } \\
\text { Union (LHMU) }\end{array}$ & $\begin{array}{l}\text { Waiters, production workers, } \\
\text { child care, security guards, other } \\
\text { low paid workers in tourism, } \\
\text { property services, health and } \\
\text { community service }\end{array}$ & Services, hospitality & 773.3 & 11.9 \\
\hline $\begin{array}{l}\text { National Tertiary } \\
\text { Education Union } \\
\text { (NTEU) }\end{array}$ & $\begin{array}{l}\text { academics, clerical and } \\
\text { administrative staff }\end{array}$ & Higher education & 203.1 & 27.4 \\
\hline $\begin{array}{l}\text { Rail Tram and Bus } \\
\text { Union (RTBU) }\end{array}$ & rail, tram and bus workers & Road and rail transport & 204.6 & 30.1 \\
\hline
\end{tabular}

Source: ABS (2008) Employee Earnings, Benefits and Trade Union Membership, Australia, Cat No 6310.0 .

(1) This column shows the industry sector where the union has a presence. For some unions this mapping is relatively straightforward with a reasonable match of the Australian Bureau of Statistics industry definitions with potential union coverage (ie the AEU, the IEU, the CPSU, the NTEU and the RTBU). However the coverage of the AMWU and especially the ASU and LHMU is much harder to map because they cover a conglomerate of industry sectors, many of them with multiple unions present. Therefore the table can be taken as only a loose approximation of their industry sectors and union density within areas relevant to their coverage.

(2) This column shows the total number of employees in the industry sector in 2006. 
Table 2 Predictors of subjective member power

\begin{tabular}{|c|c|c|c|c|c|}
\hline \multirow[b]{2}{*}{ equation no: } & \multicolumn{3}{|c|}{$\begin{array}{c}\text { all } \\
\text { delegates }\end{array}$} & \multicolumn{2}{|c|}{$\begin{array}{l}\text { trained delegates } \\
\text { only }\end{array}$} \\
\hline & (1) & $(2)$ & (3) & $(4)$ & (5) \\
\hline (Constant) & $\begin{array}{l}0.801^{*} \\
(2.403)\end{array}$ & $\begin{array}{l}0.811^{*} \\
(2.426)\end{array}$ & $\begin{array}{l}0.677^{* *} \\
(1.966)\end{array}$ & $\begin{array}{l}0.875^{\#} \\
(1.936)\end{array}$ & $\begin{array}{l}0.029 \\
(0.062)\end{array}$ \\
\hline $\begin{array}{l}\text { In an enterprise bargaining campaign, members here have a lot of } \\
\text { say in determining the content of the claim }\end{array}$ & $\begin{array}{l}0.555^{\star \star \star} \\
(11.400)\end{array}$ & $\begin{array}{l}0.555^{\star \star \star} \\
(11.402)\end{array}$ & $\begin{array}{l}0.548^{\star \star \star} \\
(11.069)\end{array}$ & $\begin{array}{l}0.599^{\star \star \star} \\
(9.893)\end{array}$ & $\begin{array}{l}0.572^{\star \star \star} \\
(9.624)\end{array}$ \\
\hline Delegates have a lot of influence in this branch & $\begin{array}{l}0.433^{\star \star \star} \\
(7.662)\end{array}$ & $\begin{array}{l}0.432^{\star \star \star} \\
(7.646)\end{array}$ & $\begin{array}{l}0.383^{\star \star \star} \\
(6.635)\end{array}$ & $\begin{array}{l}0.450^{\star * *} \\
(6.679)\end{array}$ & $\begin{array}{l}0.412^{\star \star \star} \\
(6.183)\end{array}$ \\
\hline $\begin{array}{l}\text { (change over last } 2 \text { years in) the amount of influence that } \\
\text { members have within the union branch }\end{array}$ & $\begin{array}{l}0.613^{* \star *} \\
(6.295)\end{array}$ & $\begin{array}{l}0.614^{\star \star \star} \\
(6.303)\end{array}$ & $\begin{array}{l}0.439^{\star \star \star} \\
(4.352)\end{array}$ & $\begin{array}{l}0.657^{\star \star \star} \\
(5.748)\end{array}$ & $\begin{array}{l}0.595^{\star \star \star} \\
(5.310)\end{array}$ \\
\hline $\begin{array}{l}\text { your organisation's attitude to your activities as a delegate - } \\
\text { (hostile/neutral/supportive) }\end{array}$ & $\begin{array}{l}0.322^{\star \star \star} \\
(4.467)\end{array}$ & $\begin{array}{l}0.320^{\star \star \star} \\
(4.448)\end{array}$ & $\begin{array}{l}0.291^{\star \star \star} \\
(3.982)\end{array}$ & $\begin{array}{l}0.239^{\star \star} \\
(2.798)\end{array}$ & $\begin{array}{l}0.274^{\star \star} \\
(3.274)\end{array}$ \\
\hline $\begin{array}{l}\text { not enough support from members (obstacle to being more } \\
\text { involved in the union) }\end{array}$ & $\begin{array}{l}- \\
0.465^{\star \star \star} \\
(-4.373)\end{array}$ & $\begin{array}{l}-0.468^{\star \star \star} \\
(-4.392)\end{array}$ & $\begin{array}{l}-0.302^{\star \star \star} \\
-(-2.757)\end{array}$ & $\begin{array}{l}-0.492^{\star \star \star} \\
(-3.868)\end{array}$ & $\begin{array}{l}-0.481^{\star \star \star} \\
(-3.851)\end{array}$ \\
\hline Index of delegate actions & $\begin{array}{l}0.139^{\star \star \star} \\
(3.596)\end{array}$ & $\begin{array}{l}0.138^{\star \star \star} \\
(3.546)\end{array}$ & $\begin{array}{r}0.067^{\#} \\
(1.671)\end{array}$ & & $\begin{array}{l}0.151^{\star \star} \\
(3.211)\end{array}$ \\
\hline $\begin{array}{l}\text { My organiser has taught me many valuable things about being a } \\
\text { delegate }\end{array}$ & $\begin{array}{l}0.174^{\star \star \star} \\
(3.485)\end{array}$ & $\begin{array}{l}0.171^{\star \star \star} \\
(3.378)\end{array}$ & $\begin{array}{l}0.180^{\star \star \star} \\
(3.532)\end{array}$ & $\begin{array}{l}0.213^{\star \star \star} \\
(3.382)\end{array}$ & $\begin{array}{l}0.154^{*} \\
(2.494)\end{array}$ \\
\hline It is clear to me what is expected of me as a delegate & $\begin{array}{l}0.209^{\star \star \star} \\
(3.320)\end{array}$ & $\begin{array}{l}0.206^{\star \star \star} \\
(3.259)\end{array}$ & $\begin{array}{l}0.172^{\star \star} \\
(2.662)\end{array}$ & $\begin{array}{l}0.357^{\star \star \star} \\
(4.475)\end{array}$ & $\begin{array}{l}0.239^{\star \star} \\
(2.936)\end{array}$ \\
\hline $\begin{array}{l}\text { (change over last } 2 \text { years in) the support you get from the union } \\
\text { office }\end{array}$ & $\begin{array}{l}0.301^{\star \star \star} \\
(3.315)\end{array}$ & $\begin{array}{l}0.303^{* \star *} \\
(3.330)\end{array}$ & $\begin{array}{l}0.231^{*} \\
(2.508)\end{array}$ & $\begin{array}{l}0.282^{* *} \\
(2.602)\end{array}$ & $\begin{array}{l}0.306^{\star \star} \\
(2.864)\end{array}$ \\
\hline $\begin{array}{l}\text { (change over last } 2 \text { years in) the security of employment in your } \\
\text { part of the workplace }\end{array}$ & $\begin{array}{l}0.222^{\star \star} \\
(3.011)\end{array}$ & $\begin{array}{l}0.222^{\star \star} \\
(3.007)\end{array}$ & $\begin{array}{l}0.180^{*} \\
(2.378)\end{array}$ & $\begin{array}{l}0.161^{\#} \\
(1.836)\end{array}$ & $\begin{array}{l}0.172^{\star} \\
(2.004)\end{array}$ \\
\hline (index of) confidence & $\begin{array}{l}0.071^{\star *} \\
(2.675)\end{array}$ & $\begin{array}{l}0.069^{\star *} \\
(2.598)\end{array}$ & $\begin{array}{c}0.078^{\star *} \\
(2.904)\end{array}$ & & $\begin{array}{l}0.105^{\star \star} \\
(3.122)\end{array}$ \\
\hline boss is obstacle (to being more involved in the union) & $\begin{array}{l}-0.343^{\star \star} \\
(-2.744)\end{array}$ & $\begin{array}{l}-0.345^{\star \star} \\
(-2.757)\end{array}$ & $\begin{array}{l}-0.374^{\star \star} \\
-(2.944)\end{array}$ & $\begin{array}{l}-0.285^{\#} \\
(-1.935)\end{array}$ & $\begin{array}{l}-0.384^{\star \star} \\
(-2.673)\end{array}$ \\
\hline $\begin{array}{l}\text { This branch of the union pays a lot of attention to women's issues } \\
\text { amongst its members }\end{array}$ & $\begin{array}{l}0.139 * \\
(2.569)\end{array}$ & $\begin{array}{l}0.139 * \\
(2.575)\end{array}$ & $\begin{array}{l}0.127^{*} \\
(2.312)\end{array}$ & $\begin{array}{l}0.035 \\
(0.527)\end{array}$ & $\begin{array}{l}0.047 \\
(0.718)\end{array}$ \\
\hline $\begin{array}{l}\text { (effectiveness of union support in) showing me how to develop } \\
\text { networks of people who can help me }\end{array}$ & $\begin{array}{l}0.107^{*} \\
(1.989)\end{array}$ & $\begin{array}{l}0.106^{*} \\
(1.982)\end{array}$ & $\begin{array}{r}0.124^{\star} \\
(2.268)\end{array}$ & $\begin{array}{l}0.015 \\
(0.230)\end{array}$ & $\begin{array}{l}0.009 \\
(0.141)\end{array}$ \\
\hline Union density level & & & $\begin{array}{l}0.007^{\star \star \star} \\
(3.624)\end{array}$ & & \\
\hline $\begin{array}{l}\text { (change over last } 2 \text { years in) the level of unionisation in your part } \\
\text { of the workplace }\end{array}$ & & & $\begin{array}{l}0.458^{\star \star \star} \\
(5.812)\end{array}$ & & \\
\hline
\end{tabular}


Received any delegate training

rating of overall training usefulness

$0.294^{\star \star x}$

(3.349) (3.625)

\begin{tabular}{|c|c|c|c|c|c|}
\hline R squared & 0.434 & 0.434 & .441 & 0.425 & 0.455 \\
\hline adjusted $\mathrm{R}$ squared & 0.429 & 0.429 & .435 & 0.419 & 0.447 \\
\hline $\mathrm{F}$ & $91.52^{\star \star \star}$ & $85.39^{\star \star \star}$ & $77.41^{\star \star \star}$ & $64.10^{\star \star \star}$ & $60.48^{\star \star \star}$ \\
\hline $\mathrm{N}$ & 1688 & 1688 & 1586 & 1138 & 1103 \\
\hline
\end{tabular}

*** significant at $0.1 \%$ level

** significant at $1 \%$ level

* significant at 5\% level

\# significant at $10 \%$ level 
Table 3 Correlates with subjective member power, level of union density and movement in density

\begin{tabular}{|c|c|c|c|}
\hline & $\begin{array}{c}\text { Subjective } \\
\text { union } \\
\text { power }\end{array}$ & $\begin{array}{l}\text { Estd union } \\
\text { density }\end{array}$ & $\begin{array}{l}\text { Movement in } \\
\text { union density }\end{array}$ \\
\hline $\begin{array}{l}\text { In an enterprise bargaining campaign, members here have a lot of } \\
\text { say in determining the content of the claim }\end{array}$ & $.45^{\star *}$ & $.11^{\star \star}$ & $.13^{\star \star}$ \\
\hline Delegates have a lot of influence in this branch & $.47^{\star \star}$ & $.21^{\star \star}$ & $.20^{\star \star}$ \\
\hline $\begin{array}{l}\text { (change over last } 2 \text { years in) the amount of influence that } \\
\text { members have within the union branch }\end{array}$ & $.35^{\star *}$ & $.11^{\star *}$ & $.32^{\star *}$ \\
\hline $\begin{array}{l}\text { your organisation's attitude to your activities as a delegate - } \\
\text { (hostile/neutral/supportive) }\end{array}$ & $.19^{\star *}$ & $.07^{\star *}$ & $.08^{\star *}$ \\
\hline $\begin{array}{l}\text { not enough support from members (obstacle to being more } \\
\text { involved in the union) }\end{array}$ & $-.20 \star \star$ & $-.23^{\star *}$ & $-.11^{\star \star}$ \\
\hline index of delegate actions & $.27^{\star \star}$ & $.20 * *$ & $.23^{\star *}$ \\
\hline $\begin{array}{l}\text { My organiser has taught me many valuable things about being a } \\
\text { delegate }\end{array}$ & $.39 * *$ & $.14^{\star *}$ & $.13^{\star \star}$ \\
\hline It is clear to me what is expected of me as a delegate & $.38^{\star \star}$ & $.21^{\star \star}$ & $.09 * \star$ \\
\hline $\begin{array}{l}\text { (change over last } 2 \text { years in) the support you get from the union } \\
\text { office }\end{array}$ & $.25^{\star \star}$ & $.06^{\star *}$ & $.20^{\star *}$ \\
\hline $\begin{array}{l}\text { (change over last } 2 \text { years in) the security of employment in your } \\
\text { part of the workplace }\end{array}$ & $.16^{\star *}$ & $.04^{*}$ & $.16^{\star \star}$ \\
\hline (index of) confidence & $.34^{\star \star}$ & $.19^{\star \star}$ & $.10^{\star \star}$ \\
\hline boss is obstacle (to being more involved in the union) & $-.10^{\star \star}$ & -.01 & .05 \\
\hline $\begin{array}{l}\text { This branch of the union pays a lot of attention to women's issues } \\
\text { amongst its members }\end{array}$ & $.24^{\star \star}$ & $.05^{\star}$ & $.08^{\star \star}$ \\
\hline $\begin{array}{l}\text { (effectiveness of union support in) showing me how to develop } \\
\text { networks of people who can help me }\end{array}$ & $.35^{\star *}$ & $.11^{\star \star}$ & $.15^{\star \star}$ \\
\hline Received any delegate training & $.17^{\star \star}$ & $.14^{\star \star}$ & .03 \\
\hline rating of overall training usefulness & $.25^{\star \star}$ & $.07^{\star \star}$ & $.08^{\star *}$ \\
\hline
\end{tabular}

\footnotetext{
*** significant at $0.1 \%$ level

** significant at $1 \%$ level

* significant at $5 \%$ level

\# significant at $10 \%$ level
} 
Table 4 Correlation analysis: Training and organiser mentoring

\begin{tabular}{|c|c|c|c|c|}
\hline \multirow[b]{2}{*}{ Correlation with: } & \multicolumn{2}{|c|}{ All delegates } & \multicolumn{2}{|c|}{$\begin{array}{l}\text { Trained delegates } \\
\text { only }\end{array}$} \\
\hline & $\begin{array}{l}\text { organiser } \\
\text { has taught } \\
\text { me many } \\
\text { valuable } \\
\text { things }\end{array}$ & $\begin{array}{l}\text { whether } \\
\text { received } \\
\text { any } \\
\text { training }\end{array}$ & $\begin{array}{l}\text { organiser } \\
\text { has taught } \\
\text { me many } \\
\text { valuable } \\
\text { things }\end{array}$ & $\begin{array}{l}\text { overall } \\
\text { rating of } \\
\text { effective } \\
\text { ness of } \\
\text { training }\end{array}$ \\
\hline Index of subjective power & 0.39 & 0.16 & 0.37 & 0.24 \\
\hline $\begin{array}{l}\text { effectiveness of support in showing me how to develop } \\
\text { networks of people who can help me }\end{array}$ & 0.49 & 0.19 & 0.46 & 0.29 \\
\hline enjoy being a delegate & 0.37 & 0.25 & 0.32 & 0.22 \\
\hline members are generally active & 0.22 & 0.03 & 0.22 & 0.12 \\
\hline delegates have a lot of influence in the union & 0.42 & 0.20 & 0.36 & 0.15 \\
\hline members had a lot of say in bargaining claim & 0.29 & 0.11 & 0.31 & 0.13 \\
\hline expectations of delegates are clear & 0.40 & 0.28 & 0.35 & 0.25 \\
\hline contact with delegates in this workplace & 0.32 & 0.21 & 0.26 & 0.09 \\
\hline contact with delegates other workplaces & 0.31 & 0.25 & 0.26 & 0.14 \\
\hline contact with delegates from other unions & 0.21 & 0.14 & 0.19 & 0.07 \\
\hline
\end{tabular}




\section{APPENDIX A}

\section{Variable descriptives}

Variable

minimum maximum mean deviation

index of subjective union members power

$\begin{array}{llll}0 & 14 & 9.338 & 2.743\end{array}$

In an enterprise bargaining campaign, members here have a lot of say in determining the content of the claim \#

$1 \quad 5 \quad 3.556 \quad 1.171$

Delegates $^{(\mathrm{a})}$ have a lot of influence in this branch $^{(\mathrm{a})} \#$

(change over last 2 years in) the amount of influence that members have within the union branch *

your organisation's attitude to your activities as a delegate (hostile/neutral/supportive)

$1 \quad 5 \quad 3.350 \quad 1.085$

not enough support from members (obstacle to being more involved in the union)

index of delegate actions

My organiser has taught me many valuable things about being a delegate \#

$\begin{array}{llll}1 & 5 & 3.237 & 1.286\end{array}$

It is clear to me what is expected of me as a delegate \#

(change over last 2 years in) the support you get from the union office *

$\begin{array}{llll}1 & 5 & 3.918 & 0.989\end{array}$

(change over last 2 years in) the security of employment in your part of the workplace *

(index of) confidence

boss is obstacle (to being more involved in the union)

$\begin{array}{llll}0 & 2 & 1.149 & 0.579\end{array}$

$\begin{array}{llll}1 & 3 & 2.156 & 0.762\end{array}$

$\begin{array}{llll}0 & 1 & 0.453 & 0.498\end{array}$

$\begin{array}{llll}0 & 6 & 4.310 & 1.493\end{array}$

This branch of the union pays a lot of attention to women's issues amongst its members \#

(effectiveness of union support in) showing me how to develop networks of people who can help me \#

Union density level

(change over last 2 years in) the level of unionisation in your part of the workplace *

$\begin{array}{llll}0 & 2 & 1.293 & 0.609\end{array}$

$\begin{array}{llll}0 & 2 & 0.820 & 0.705\end{array}$

$\begin{array}{llll}0 & 12 & 9.037 & 2.363\end{array}$

$\begin{array}{llll}0 & 1 & 0.253 & 0.435\end{array}$

Received any delegate training

rating of overall training usefulness

$\begin{array}{llll}1 & 5 & 3.646 & 1.003\end{array}$

$\begin{array}{llll}1 & 5 & 2.941 & 1.147\end{array}$

$\begin{array}{llll}1 & 100 & 67.1 & 28.9\end{array}$

$\begin{array}{llll}0 & 2 & 1.160 & .718\end{array}$

$\begin{array}{llll}0 & 1 & 0.652 & 0.476\end{array}$

$\begin{array}{llll}1 & 5 & 4.05 & 8.11\end{array}$

\# 1 = strongly disagree, 5 = strongly agree

* 0 = gone down, 1 = stayed the same, 2 = gone up 
(a) For unions where the term union 'representative' was normally used to describe union 'delegate', this term was substituted into the interviewer's script. Likewise, where 'division' rather than 'branch' was the main operational unit, this term was used in the script. 